\title{
Pressure build-up test analysis of the hydrocarbon reservoir system with multiphase flow
}

The Mining-Geology-Petroleum Engineering Bulletin UDC: 622.3

DOI: $10.17794 / \mathrm{rgn} .2018 .3 .8$

Review scientific paper

\author{
Sonja Koščak Kolin'; Tomislav Kurevija ${ }^{1}$; Dominik Grebenar ${ }^{1}$
}

${ }^{1}$ University of Zagreb, Faculty of Mining, Geology and Petroleum Engineering, Pierottijeva 6, 10000 Zagreb, Croatia

\begin{abstract}
The present work focuses on the determination of absolute permeability in a hydrocarbon reservoir whose pressure is under the bubble point. The simulation of the homogenic reservoir and well with the simultaneous flow of oil and gas is performed using the Eclipse1oo software. The main purpose of the simulation is to obtain pressure build-up tests for two simulated reservoir systems, since the well testing technology requires the shut-in period, which increases the costs of the real well production cycle. In the first simulation it is presumed that the well is not damaged, having the skin effect equal to zero, while in the second one, the skin effect of the well in the same reservoir is 9.44. The aim is to compare the results of the pressure build-up test analysis for both cases. In each case, permeability is firstly calculated using four methods, given by different authors. The theoretical background and the process of obtaining the required results are given for each approach. Results are compared with the permeability as determined by the pressure transient analysis, using the Saphir software, for both the ideal and the damaged well. Differences in results are presented and discussed. Conclusions could be applied to similar real reservoir systems with the multiphase fluid flow in the porous media.
\end{abstract}

\section{Keywords:}

multiphase flow, pressure transient analysis, reservoir permeability, well testing.

\section{Introduction}

One of the key processes in petroleum engineering is collecting data of the physical properties of the hydrocarbon reservoir. The quality of the reservoir simulation depends not only on the sophisticated program that is applied, but also on the accuracy of the collected data for the particular reservoir and well system. The main goal was to compare the determination of rock permeability based on pressure build-up tests, obtained by two simulated models of the same reservoir whose pressure is under the bubble point, $p_{b}$. An accurate value of permeability is of great importance as it influences each production model used in the determination of well productivity that depends on the changes in the reservoir during all phases. Since the well productivity value is significant for the planning of the complete production cycle, permeability can also affect economical aspects of any reservoir system, because the pressure build-up test requires financial investment and a shut-in period (Karasalihović-Sedlar et al, 2017; Strpić et al, 2017).

Difficulties in the creation of the reliable reservoir model lie in the fact that hydrocarbon reservoirs are usually on a scale of hundreds of meters to kilometres and petro-physical properties of the whole system are com-

Corresponding author: Sonja Koščak Kolin

sonja.koscak-kolin@rgn.hr plex. At the same time, the input data for the simulation are usually restricted and obtained from a small number of well measurements. There are a few possible sources in collecting the data for the reservoir model: seismic and well logging, laboratory core analysis, wireline testing, well testing (pressure build-up tests, etc.). The most favourable approach to achieve a reliable model is the usage of data from more sources, which is usually not convenient. In this paper, the reservoir model with the production well, simulated in the licensed Eclipse 100 program, can almost be used instead of the real system with similar physical properties of the reservoir and well. The main purpose of the created model was to simulate the pressure build-up tests for the multiphase flow of oil and gas, for the same well with and without the skin effect. When the well is not damaged, meaning that the permeability near the well-bore is not changed, the four methods for the determination of permeability are compared to the results obtained by the Saphir program. The main reason for these calculations is to investigate which one of the methods for the multiphase flow gives permeability results nearest to its value in the simulation, firstly for the ideal case (undamaged well or well with no damage near the wellbore region). The original reservoir permeability in the well-bore entered in the simulation is $15 \mathrm{mD}\left(15 \times 10^{-15} \mathrm{~m}^{2}\right)$. This could be a helpful tool to choose the best option to determine the permeability in a similar real situation, when the well is 
damaged during various operations. In the pressure build-up test analysis of the simulated reservoir with the multiphase flow of oil and gas, it is presumed that the skin factor is equal to 9.44 and the corresponding permeability is calculated. Such an approach can serve as a guideline to determine permeability as accurately as possible when there is an abundance of data collected by well testing or some other technique. This also provides an opportunity to reduce the costs of the production cycle (Ahmed, 2010; Lee, 1982).

The pressure build-up test analysis is based on the transient state of radial flow from the reservoir to the well for a single phase in a porous medium. Different authors propose numerous methods for the multiphase flow that are also based on equations and solutions for a single fluid flow. The transient pressure analysis is the theory of unsteady-state, single-phase radial flow that is based on a few assumptions concerning the flow near the wellbore (Stewart, 2011). Firstly, the reservoir is homogeneous and isotropic with respect to both the porosity and permeability, which are also considered to be constant and thus independent of pressure. Then, the producing well is completed across the whole reservoir thickness, thus ensuring radial flow and the formation is completely saturated with a single fluid and is uniformly thick.

The diffusivity equation, based on Darcy's law and continuity equation, describing the unsteady-state, radial flow is:

$$
\frac{\partial^{2} p}{\partial r^{2}}+\frac{1}{r} \frac{\partial p}{\partial r}=\frac{\phi \mu c}{k} \frac{\partial p}{\partial t}
$$

where:

$$
\begin{aligned}
& p \text { - pressure (bar), }(\mathrm{Pa}) \\
& r-\operatorname{radius}(\mathrm{m}) \\
& f-\operatorname{porosity}(-) \\
& m-\operatorname{viscosity}(\mathrm{Pa} \mathrm{s}) \\
& c-\operatorname{compressibility~}\left(\mathrm{Pa}^{-1}\right) \\
& k-\operatorname{rock} \text { permeability }\left(\mathrm{m}^{2}\right) \\
& t-\operatorname{time}(\mathrm{s})
\end{aligned}
$$

In order to determine the solutions of the equation, an initial condition and two boundary conditions must be specified. The fundamental solutions of interest in the development of pressure analysis methods are those for the case of flow into a centrally located well at a constant volumetric rate of production $q$. The three basic cases of interest are infinite reservoir, bounded reservoir and constant pressure outer boundary.

The analytical solution of the differential system for an infinite reservoir, which refers to unsteady or transient flow, is:

$$
p_{w f}(t)=p_{i}-\frac{q B \mu}{2 \pi k h} \frac{1}{2}\left(\ln \frac{k t}{\phi \mu c r_{w}^{2}}+0.80907\right)
$$

where:

$$
\begin{aligned}
& \mathrm{q}-\text { flow rate }\left(\mathrm{m}^{3} / \mathrm{s}\right) \\
& B \text { - volume factor }\left(\mathrm{m}^{3} / \mathrm{m}^{3}\right) \\
& h-\text { reservoir net thickness }(\mathrm{m}) \\
& r_{w}-\text { well radius }(\mathrm{m}) .
\end{aligned}
$$

The additional pressure drop due to the skin effect is defined by:

$$
\Delta p_{s}=p_{w f, \text { ideal }}-p_{w f, \text { real }}=\frac{q B \mu}{2 \pi h} \ln \frac{r_{s}}{r_{w}}\left(\frac{1}{k_{s}}-\frac{1}{k}\right)
$$

The near wellbore zone with reduced permeability $k_{s}$, is located between the well radius $r_{w}$ and the radius of the skin effect $r_{s}$. The skin factor is:

$$
s=\left(\frac{k}{k_{s}}-1\right) \ln \frac{r_{s}}{r_{w}}
$$

Thus, if the permeability in the skin zone is less than that in the rest of the formation, $s$ will be positive; if the permeabilities are equal, $s$ will be zero. Finally, if the permeability in the skin is greater than that in the formation, which can be the consequence of fracturing or acidizing, $s$ will be negative.

The turbulent flow in the near wellbore zone that is presented in Figure $\mathbf{1}$ as nonDarcy diffusion causes an extra pressure drop, can be expressed by skin factor depending on the rate $(\mathrm{ds} / \mathrm{dq})$. This is also a part of the total skin $s$.

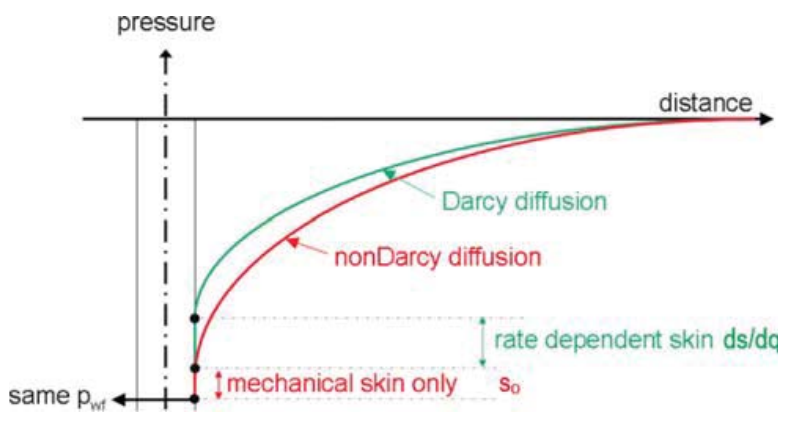

Figure 1: Influence of the skin factor on the flow rate

\section{Periods of the pressure build-up test}

Pressure build-up testing entails shutting in a producing well and recording the closed-in bottom-hole pressure $p_{w s}$ as a function of time (see Figure 2). Figures 2 to $\mathbf{5}$ are based upon the data of the pressure build-up test analysis, used to obtain the results, which are discussed and presented in Tables $\mathbf{1}$ and $\mathbf{2}$. As shown in Figure 2, $t_{p}$ is the production time and $\Delta \mathrm{t}$ is the running shut-in time. The resulting pressure build-up curve is analyzed for reservoir properties. The most common analysis requires that the well produces at a constant rate, either from the start-up or long enough to establish a stabilized pressure distribution before shut-in. If possible, the flowing bottom-hole pressure prior to shut-in should also be recorded, which is essential if an estimate of skin is required (Gringarten, 2008).

There are several ways to analyse the results of a build-up test. The most popular is Horner's method, based on the supposition that the reservoir is infinite, 


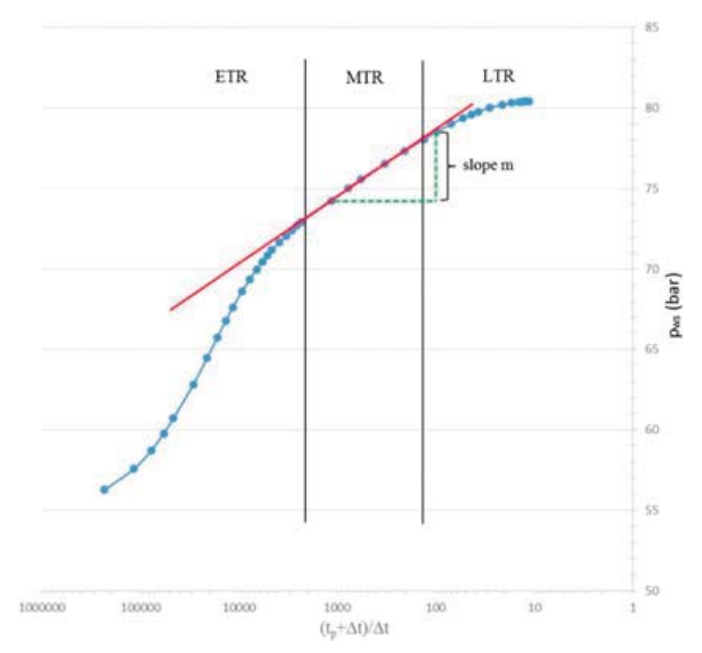

Figure 2: Periods of the build-up test on Horner's plot

meaning that the transformed solution for transient flow can be applied. Horner's plot predicts a linear relationship between $p_{w s}$ and $\ln \left(\left(\mathrm{t}_{\mathrm{p}}+\Delta \mathrm{t}\right) / \Delta \mathrm{t}\right)$, presented in Figure 2 as a MTR (middle transient region). In practice, even though the well is shut-in, the after flow, caused by wellbore storage, has a significant influence on the pressure build-up data, which is interpreted as an ETR (early transient region). In the LTR (late transient region) pressure response is influenced by reservoir boundaries or by interference of production wells in the vicinity (Lee et al., 2003; Matthews and Russell, 1967). In case of tests with multiphase flow in the reservoir, the methods that deal with a single-phase fluid flow need to be modified. Several interpretation methods, presented in the oil industry, are discussed in this paper.

\section{Methods for tests with multiphase flow}

The easiest method to use is Perrine's method, while others are more rigorous and require relative permeability curves to be known beforehand. This is not always the case when the pressure build-up test is performed.

\subsection{Perrine's method}

Perrine's method assumes that fluid distribution is uniform. It also makes further simplifying statements, that capillary pressures are negligible. These are not verified in the wellbore vicinity in reservoirs, whose pressure is lower than the bubble point pressure. Since the widest pressure variations take place in the near-well zone, this is also where the widest variations in gas saturation are located. The fact that variations in saturation are disregarded in the vicinity of the well affects the skin value. The uniform-saturation hypothesis is approximately verified at a certain distance from the wellbore (Perrine, 1956).

In Perrine's method, the multiphase fluid is considered as one single phase where various fluids are dis- persed, and is treated as an equivalent one-phase fluid. The effective permeability of the formation in each phase can be determined on the basis of the flow rate of each phase. It means that the slope $m$ on the semi-log straight line allows the following to be determined:

$$
\begin{gathered}
k_{o}=\frac{0,183 q_{o} B_{o} \mu_{o}}{m h} \\
k_{g}=\frac{0,183\left(q_{g}-q_{o} R_{s}\right) B_{g} \mu_{g}}{m h} \\
k_{w}=\frac{0,183 q_{w} B_{w} \mu_{w}}{m h}
\end{gathered}
$$

The skin is equivalent to:

$$
s=1,151\left[\frac{p_{1 h r}-p_{w f}}{m}-\log \left(\frac{\lambda_{t}}{\phi c_{t} r_{w}^{2}}\right)+0,35\right]
$$

The skin expression involves the overall properties of the equivalent fluid: mobility (1), and compressibility (c). The value of the skin must be considered with caution as this method puts forward the hypothesis that saturation is uniform around the well. In fact, the gas saturation around a production well is greater around the wellbore. This can be seen as a negative skin, which is the main weakness of this method.

\subsection{Raghavan's method}

In his approach, Raghavan gave a similar solution that is valid for gas wells, where the pseudo pressure function is introduced. According to the solution for the steady state of flow, the rate is defined as:

$$
q_{o}=\frac{k h}{1,57 \ln \frac{r_{e}}{r}} \int_{p}^{p_{e}} \frac{k_{r o}\left(S_{o}\right)}{\mu_{o} B_{o}} d p
$$

and $m(p)$ is function of pseudo pressure:

$$
m(p)=\int_{p_{b}}^{p} \frac{k_{r o}\left(S_{o}\right)}{\mu_{o} B_{o}} d p
$$

where:

$k_{r o}$ - relative permeability of oil (ratio)

$S_{o}$ - oil saturation (-).

Raghavan succeeded in determining the function of pseudo pressure which is in relation to data of the pressure build-up test. In this method, it is necessary to have relative permeability curves and saturation of the fluids (Raghavan, 1976).

In the following formula for the dimensionless pressure drop and dimensionless pseudo pressure drop, it is assumed that the reservoir is horizontal, homogeneous and isotropic, and unaffected by gravity:

$$
\begin{aligned}
& p_{D}\left(r_{D}, t_{D}\right)=\frac{2 \pi k h}{q_{o} B_{o i} \mu_{o i}}\left[p_{i}-p(r, t)\right] \\
& m_{D}\left(r_{D}, t_{D}\right)=\frac{2 \pi k h}{q_{o}}\left[m\left(p_{i}\right)-m(r, t)\right]
\end{aligned}
$$




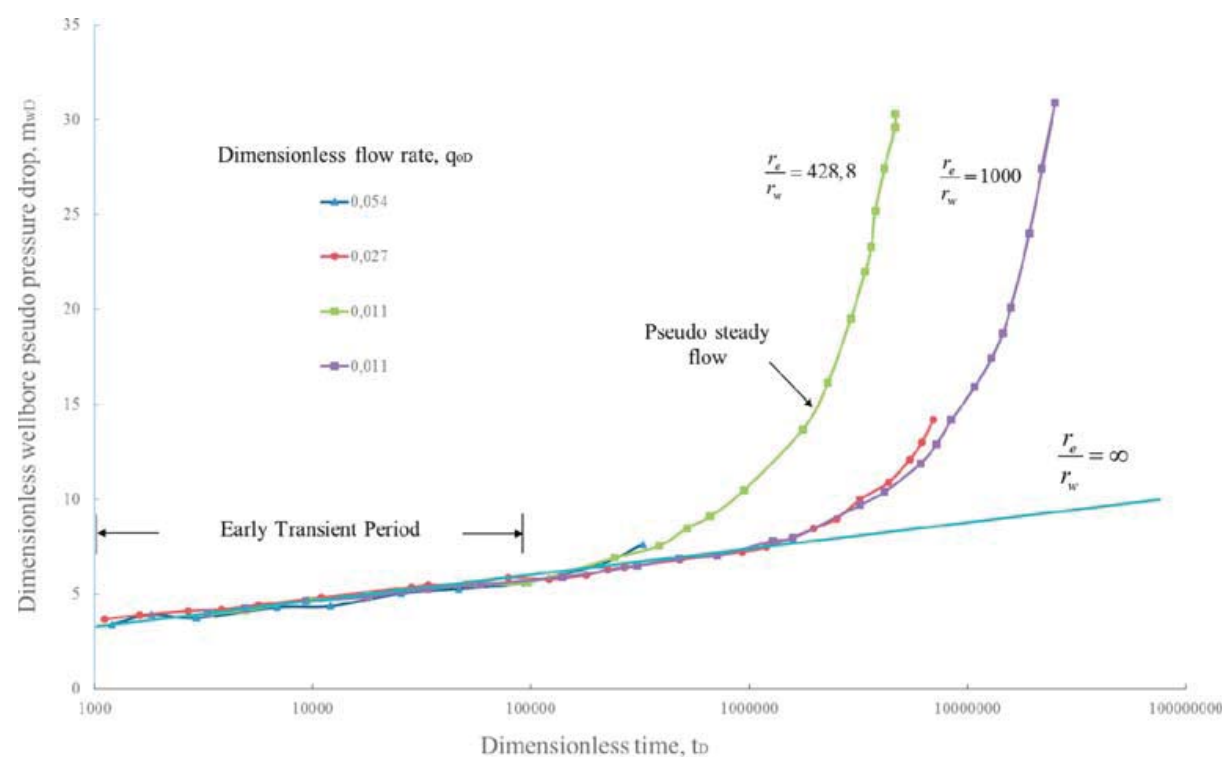

Figure 3: Dimensionless pseudo pressure drop $\mathrm{m}_{\mathrm{WD}}$ in relation to dimensionless time $t_{\mathrm{D}}$

Figure 3 shows that the slope $m$ is constant during the period of the transient state of flow, which is a crucial condition in the usage of the pseudo pressure method.

\subsection{Al-Khalifah's method}

The multiphase flow equation, neglecting gravity and capillarity effects, is derived and can be reduced to:

$$
\frac{\phi c_{t}}{\lambda_{t}} \frac{\partial p}{\partial t}=\nabla^{2} p+\nabla p \cdot \nabla\left[\ln \left(\frac{k_{o}}{\mu_{o} B_{o}}\right)\right]
$$

The linear relation of $\left(\mathrm{k}_{\mathrm{o}} / \mathrm{m}_{\mathrm{o}} \mathrm{B}\right)$ can be expressed as:

$$
\frac{k_{o}}{\mu_{o} B_{o}}=a p
$$

where $a$ is constant.

It was determined that the saturation value is stabilized in the well on the inner boundary of the reservoir during well testing. When the saturation is stabilized, effective permeability for oil, $k_{o}$, is also stabilized. That is the reason why parameter $k_{o}$ is decreasing almost to a constant value and remains mostly this value for the duration of testing, wherefrom it follows that the change of the $\left(\mathrm{k}_{\mathrm{o}} / \mathrm{m}_{\mathrm{o}} \mathrm{B}_{\mathrm{o}}\right)$ term to pressure is also linear (see Figure 4). When this condition is fulfilled, the solution of the multiphase flow equation (Equations 13) is:

$$
\begin{gathered}
p_{w f}^{2}-p_{i}^{2}(r, t)= \\
=\frac{0,366 q_{o}}{a h}\left[\log t+\log \left(\frac{\lambda_{t}}{\phi c_{t} r_{w}^{2}}\right)-3,228+0,869 s\right]
\end{gathered}
$$

If the $\left(\mathrm{k}_{\mathrm{o}} / \mathrm{m}_{\mathrm{o}} \mathrm{B}_{\mathrm{o}}\right)$ term is linear to pressure, slope $a$ can be calculated for each pressure (Al-Khalifah et al., 1987). In this case, the corresponding relation for effec-

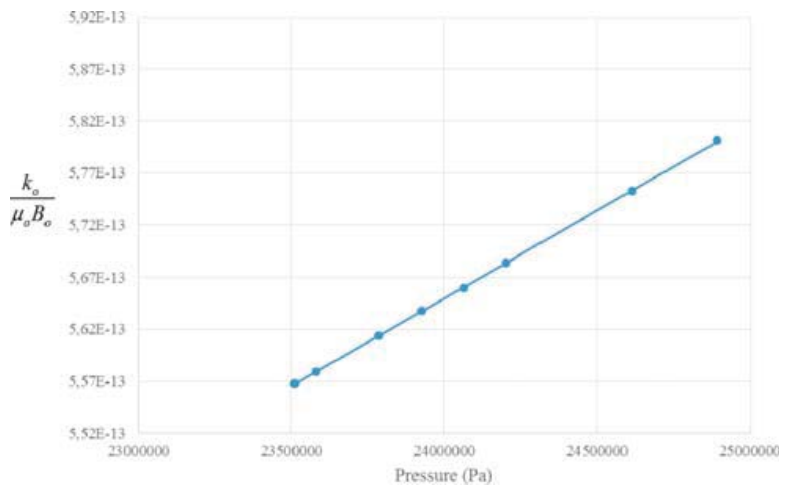

Figure 4: The linear $\left(\mathrm{k}_{\mathrm{o}} / \mathrm{m}_{\mathrm{o}} \mathrm{B}_{\mathrm{o}}\right)$ relation to pressure

tive permeability of oil, calculated from the build-up test, is:

$$
k_{o}=\frac{2 \times 0,183 \bar{p} q_{o} B_{o} \mu_{o}}{m h}
$$

and effective permeability of gas is:

$$
k_{g}=\frac{\left(R-R_{s}\right) B_{g} \mu_{g}}{\mu_{o} B_{o}} \times k_{o}
$$

The skin factor equation, based on the pressure buildup test data, in the Al'Khalifah method is:

$$
s=1,1513\left[\left(\frac{p_{1 h r}^{2}-p_{w f}^{2}(\Delta t=0,0)}{m}\right)-\log \left(\frac{\lambda_{t}}{\phi c_{t} r_{w}^{2}}\right)-3,91\right]
$$

\subsection{Kamal and Pan's method}

Kamal and Pan published a multiphase analysis method in 2011, that produces values of absolute permeability as a result, which are consistent with the relative per- 
meability relations. The procedure consists of a few steps (Kamal and Pan, 2011), beginning with calculations of effective permeabilities and of permeability ratio: $k_{r o} / k_{r g}=k_{o} / k_{g}$. These relations should be the same as those selected for use in the numerical reservoir simulation model. As shown in Figure 5, from these relative permeability curves, the ratio $k_{r o} / k_{r g}$ as a function of saturation can be derived. The average value of gas (or oil) saturation in the tested area of the reservoir can be obtained, using the value of $k_{o} / k_{g}$ from test analysis. Finally, absolute permeability can then be calculated from:

$$
\begin{gathered}
k=\frac{k_{g}}{k_{r g}} \\
k=\frac{k_{o}}{k_{r o}}
\end{gathered}
$$

where:

$\mathrm{k}_{\mathrm{g}}$ - effective permeability of gas $\left(\mathrm{m}^{2}\right)$

$\mathrm{k}_{\mathrm{o}}^{\mathrm{g}}$ - effective permeability of oil $\left(\mathrm{m}^{2}\right)$.

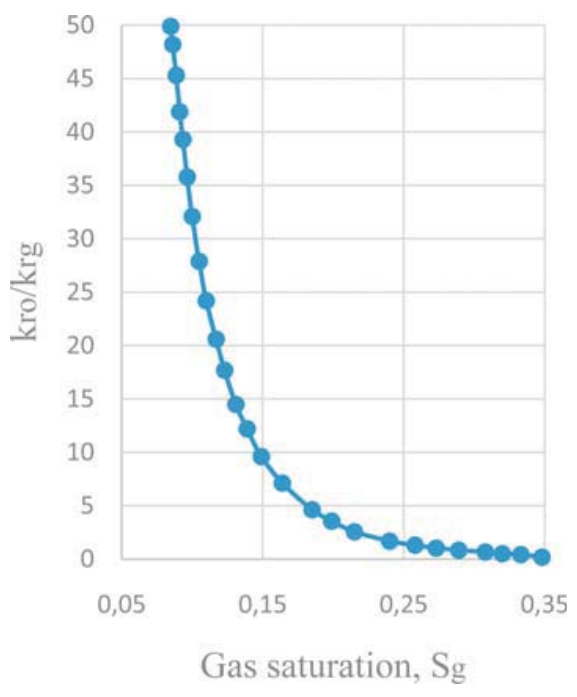

Figure 5: Ratio of oil to gas permeability

The application of Kamal-Pan's method in a hydrocarbon reservoir has proven that it can be used to calculate consistent values of absolute permeability of the formation under a two-phase flow condition similar to what is calculated during the single-phase flow period.

\section{Reservoir simulation}

Reservoir simulation, as well as computing of material balance, is a form of geological and numerical modelling, used to quantify and interpret physical properties and changes, with the possibility of predicting their behavior in the future. In reservoir simulation, a reservoir is divided into a certain number of unit cells in three di- mensions, and changes in the properties of the reservoir and reservoir fluids are modelled, taking into concern the change of space- and time-flow in a series of different steps. As in the material balance equation, the total mass of the system remains unchanged.

For comparison of the aforementioned four approaches to the pressure build-up test analysis for the multiphase flow of oil and gas, it was necessary to create a simulation model of the reservoir in the Eclipse 100 program. The model computes the pressure and saturation in each cell implicitly, in other words, it solves a system of linear equations by iterative procedure. The model consists of reservoir and fluid descriptions, defined initial conditions, descriptions of wells, and given production data. This data is entered in the input text file, which also contains keywords that determine the simulator mode.

Subsequently, the data obtained from the Eclipse reservoir simulation (Eclipse 100, 2017) is converted and the Saphir program (License \#9643) is used to calculate permeability and skin.

\subsection{Input data for the dynamic reservoir models}

A cylindrically shaped reservoir with an internal radius of $0.0762 \mathrm{~m}$ and outer radius of $150 \mathrm{~m}$ is created. The thickness of the reservoir is $21 \mathrm{~m}$. The reservoir is divided into 180 cells, with 60 cells in three layers of 7 $\mathrm{m}$ (see Figure 6). Cap rock is located at a depth of 2000 $\mathrm{m}$ and bedrock at a depth of $2021 \mathrm{~m}$. All input values are chosen for the sake of the illustration of the common hydrocarbon reservoir system, so that the results of the research could be applied for the practical usage in any reservoir having the similar basic properties of the rock and well. This is a proven hydrocarbon reservoir with production. PVT calculator program was used to calculate the PVT data (PVT Calculator, 2017). In the beginning of production, reservoir pressure is equal to the bubble pressure of $104.93 \mathrm{bar}$, and the saturation of oil is $S_{o}=1$. For the first model, with no skin, permeability in the direction of the radius and clockwise (by angle increase) is set at $15 \mathrm{mD}$, and by z-axis at $3 \mathrm{md}$. In the other model, the one that contains skin, permeability is the same as in the first model, except that in the 18 cells that are the closest to well, permeability is $0.11585 \mathrm{mD}$, which represents the skin 9.438 between the radius of the well $(0.0762 \mathrm{~m})$ and the radius of the skin $(0.1627$ $\mathrm{m})$. Porosity of the reservoir is $12 \%$. Relative permeabilities of oil and gas are taken from Raghavan. Oil density is $800 \mathrm{~kg} / \mathrm{m}^{3}$, water $999 \mathrm{~kg} / \mathrm{m}^{3}$ and gas $0.86 \mathrm{~kg} / \mathrm{m}^{3}$. The compressibility of the reservoir is calculated according to Ahmed's formula (2010). For 12\% porosity, the compressibility is $6.53 \times 10^{-5} \mathrm{bar}^{-1}$. A well, whose diameter is $0.1524 \mathrm{~m}$ is located at the centre of the reservoir and is in contact with the reservoir in all three layers. Production tubing, whose inner diameter is $0.062 \mathrm{~m}$, is located in the well, and is used to calculate the well- 
bore storage effect. In both cases, the well produces 50 $\mathrm{m}^{3}$ of oil per day and closes after 231 days of production. The static pressures at the bottom of the well are used for the pressure build-up test analysis. The average saturation of the gas reservoir at the moment of closing of the well is $S_{g}=10.2 \%$. The FloViz.program, which is found in the Eclipse.program package, can graphically illustrate the properties of the simulated reservoir, as well as its shape. Figure 6 shows the initial saturation of the oil reservoir with the production well at the centre of the reservoir.

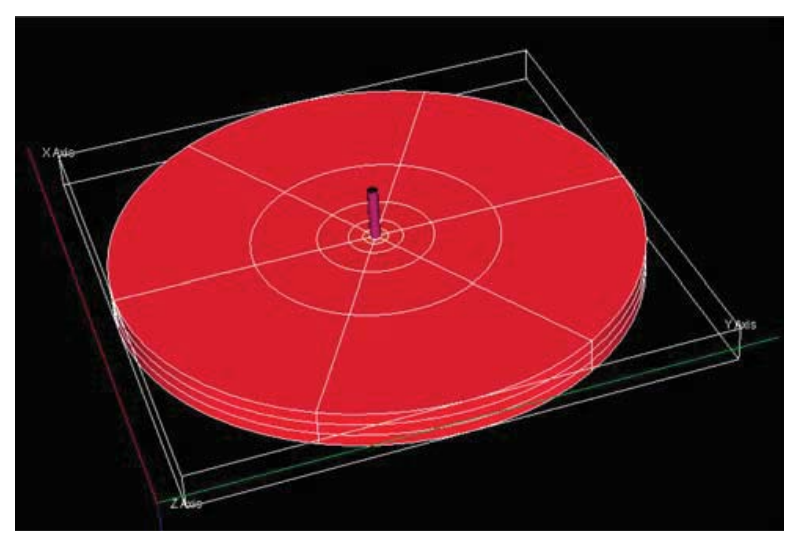

Figure 6: Reservoir model with the production well

Since the Eclipse100 output data is in the form of extensive tables, for the mentioned input data, it could not all be displayed in this paper. Therefore, Tables $\mathbf{1}$ and $\mathbf{2}$ in the case of the simulated reservoir model with and without skin, show only results for all methods, which are based on the data of simulated pressure build-up tests.

\subsection{Results obtained by the analytical method}

Calculation of the results obtained by the simulated pressure build-up test data, in case of the reservoir model without skin, is illustrated here using the Raghavan's method, where pseudo pressure, $m(p)$, is given in dependence of time $D t$.

From the diagram, the slope of $m$, which is $3.1 \times 10^{8}$ $\mathrm{Pa} / \mathrm{s}$, is calculated. Also, the value of permeability $k$ is determined and totals:

$$
\begin{aligned}
k & =\frac{0,183 q}{m h}=\frac{0,183 \times(50 / 86400)}{3,1 \times 10^{8} \times 21}= \\
& =16,48 \times 10^{-15} \mathrm{~m}^{2}=16,48 \mathrm{mD}
\end{aligned}
$$

Permeability, as one of the common results of all methods discussed, is shown in Table 1. In contrast to the default value of the absolute permeability of $15 \mathrm{mD}$, on the basis of which the simulation model was created, the value of permeability of $16.48 \mathrm{mD}$, determined by the pseudo pressure method, gives a certain deviation (Houze, 2002).

When compared to the results of the other methods, this deviation for the reservoir model without skin can be taken as an acceptable result, because each other method obtains higher deviations. In practice, the determination of rock permeability is always based on the implementation of the described methods and on the selection of the most accurate result.

\subsection{Results obtained by the Saphir program}

Saphir is the standard PTA (pressure transient analysis) software, used by major international and national oil companies, independents and service companies (Saphir tutorial, 2017). The diagnostic plot of choice is the log-log diagram (see Figure 7 and Figure 10) where the pressure and the Bourdarot derivative allow the identification of reservoir geometry and properties (Bourdarot, 1998). In the PVT section, the program can handle single or multiphase fluids. Linear problems can be modelled with constant fluid properties (Koščak Kolin et al, 2013), while nonlinear problems are modelled with correlations as PVT parameters vary with pressure.

Pressure build-up test data are firstly analyzed by the standard model with simultaneous flow of oil and gas and matching of tested and modelled data is presented in Figure 7. Matching of the nonlinear model for the same build-up test was also performed and results of both standard and nonlinear analyses of the simulated reservoir model without skin can be seen in Table 1.

Saphir also offers the option to use an Improve tool to fit between the actual data and the current theoretical model. This option was not used, as it changes the input parameters from the Eclipse simulation, such as initial reservoir pressure or drainage radius. Changes of those parameters produced large deviations of the input data from the simulated reservoir model system. In order to obtain as good a match as possible, values of these parameters were changed manually.

The best match of the tested and modelled data for the standard model of the reservoir system without skin on the log-log plot (see Figure 7) is achieved for the well-

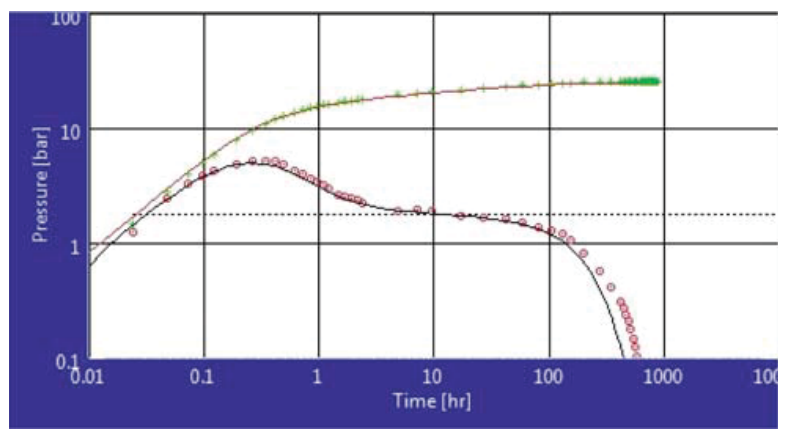

Figure 7: Log-log diagram of the standard model for the reservoir system without skin 


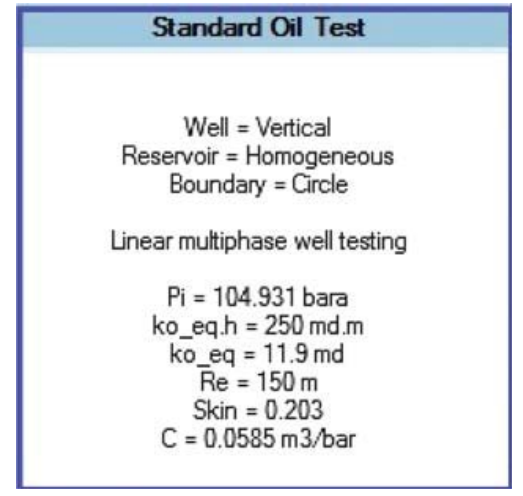

Figure 8: Results preview of the standard model for the reservoir without skin

bore storage value of $0.0585 \mathrm{~m}^{3} / \mathrm{bar}$. According to this analysis, permeability is $11.9 \mathrm{mD}$, which is also shown in Figure 8.

Nonlinear analysis of the same test differs from the standard test because it was necessary to plot the reservoir's shape as it could not be chosen from the program (see Figure 9). Entering the relative permeability curves was also required.

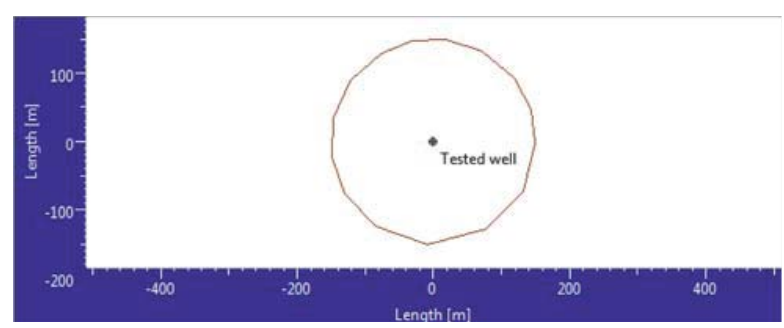

Figure 9: Cylindrical reservoir with radius $\mathrm{r}=150 \mathrm{~m}$

In the nonlinear analysis, a good match of tested and modelled data of the reservoir system without skin is also obtained and the resulting permeability of $16.7 \mathrm{mD}$ is given in Table 1. The pressure build-up test of the reservoir model with skin of 9.44 is also obtained as output data of the Eclipse100 simulation. This simulated test data is analyzed by the standard and nonlinear model in the Saphir program as well. The cylindrical reservoir model with a radius of $150 \mathrm{~m}$ is also selected. After the modelling of the skin values using the standard analysis, the best matching was achieved for the skin that totals 12 , where the rate dependent skin is $\mathrm{ds} / \mathrm{dq}=0.03$ $\mathrm{m}^{3} / \mathrm{d}$. Without introducing the rate dependent skin value in the standard model, matching of the tested and modelled data on the log-log diagram for the reservoir system with skin was not acceptable.

In the case of nonlinear modelling of the tested data for the reservoir system with skin, determining the skin parameter was the most complex issue. Combinations in range of skin value from 7.5 to 10 , gave similar interpretations of log-log plots. As the best option, although without the high level of matching accuracy, the model with the 7.5 skin was chosen. This interpretation is presented in Figure 10, and the resulting permeability of $14.3 \mathrm{mD}$ is shown in Table 2, alongside other results for the reservoir with skin.

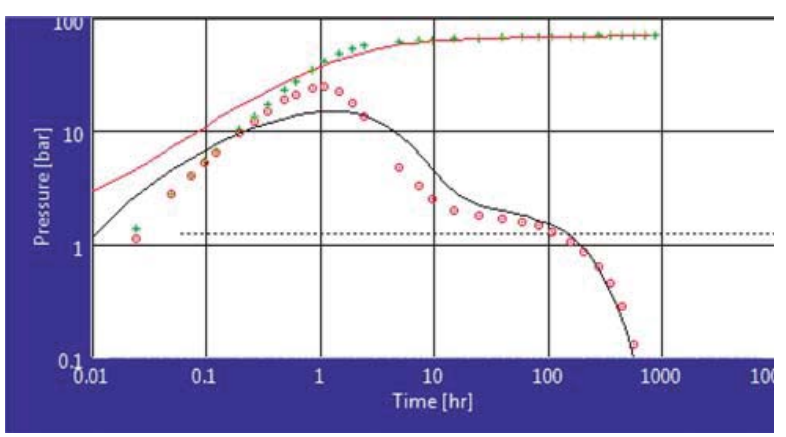

Figure 10: Log-log diagram of the nonlinear model for the reservoir system with skin

\section{Results and discussion}

Table 1 presents all the results for the simulated reservoir model without skin, based on its pressure build-up test data. The aim was to calculate the absolute permeability for the case of the multiphase flow in the reservoir and to analyze the accuracy of the results determined by the presented methods. Compared to the permeability of $15 \mathrm{mD}$, entered in the simulated model, the best result among four analytical methods is achieved by the Kamal and Pan's method, which is $16.14 \mathrm{mD}$. This could be expected as their procedure uses effective permeabilities and relative permeability curves that should be collected from other data sources. A good permeability result is also obtained by the Raghavan's method $(16.48 \mathrm{mD})$, but it cannot be accepted here, as the belonging value of skin is 7.07 instead of zero. The main disadvantage of the remaining two analytical methods is that only effective permeabilities can be calculated. Also, the deviation in skin of 8.08, as determined by Perrine's method follows from the explained fact that gas saturation around a production well is greater around the wellbore.

In the standard model case (see Figure 7), the Saphir program gives better results of absolute permeability than analytical methods, although it is only $11.9 \mathrm{mD}$, but this value is in accordance with the skin (0.2). It is due to the fact that software uses the nonlinear regression method in matching of the tested data into the model, giving the most accurate values in both models, standard and nonlinear. The best solution for the multiphase flow is achieved by the nonlinear model, where the value of the skin is 0 and corresponding permeability is $16.7 \mathrm{mD}$. This is the result of good matching of tested and modelled data in the log-log diagram.

Table 2 presents the results of the simulated reservoir model with skin and its pressure build-up test data for 
Table 1: Results for the simulated reservoir model without skin

\begin{tabular}{|l|l|l|l|l|}
\hline \multicolumn{6}{|l|}{ RESERVOIR MODELWITHOUT SKIN } \\
\hline & $\mathrm{k}, \mathrm{mD}$ & $\mathrm{k}_{\mathrm{o}}, \mathrm{mD}$ & $\mathrm{k}_{\mathrm{g}}, \mathrm{mD}$ & $\mathrm{s}$ \\
\hline Input data: & 15 & & & 0 \\
\hline Results: & \multicolumn{5}{l|}{} \\
\hline 1. Perrine's method & & 7.47 & 0.23 & 8.08 \\
\hline 2. Raghavan's method & 16.48 & & & 7.07 \\
\hline 3. Al-Khalifah's method & & 7.77 & 0.17 & -1.09 \\
\hline $\begin{array}{c}\text { 4. Kamal and Pan's } \\
\text { method }\end{array}$ & 16.14 & & & \\
\hline $\begin{array}{c}\text { Results of Saphir program: } \\
\text { 1. Standard model }\end{array}$ & 11.90 & & & 0.20 \\
\hline 2. Nonlinear model & 16.70 & & & 0.00 \\
\hline
\end{tabular}

Table 2: Results for the simulated reservoir model with skin

\begin{tabular}{|l|l|l|l|l|}
\hline RESERVOIR MODELWITH SKIN \\
\hline & $\mathrm{k}, \mathrm{mD}$ & $\mathrm{k}_{\mathrm{o}}, \mathrm{mD}$ & $\mathrm{k}_{\mathrm{g}}, \mathrm{mD}$ & $\mathrm{s}$ \\
\hline Input data: & 15 & & & 9.44 \\
\hline Results: & \multicolumn{4}{l|}{} \\
\hline 1. Perrine's method & & 8.48 & 0.26 & 9.10 \\
\hline 2. Raghavan's method & 19.31 & & & 10.6 \\
\hline 3. Al-Khalifah's method & & 8.35 & 0.19 & 0.27 \\
\hline $\begin{array}{c}\text { 4. Kamal and Pan's } \\
\text { method }\end{array}$ & 16.98 & & & \\
\hline $\begin{array}{c}\text { Results of Saphir program: } \\
\text { 1. Standard model }\end{array}$ & 13.80 & & & 12.00 \\
\hline 2. Nonlinear model & 14.30 & & & 7.50 \\
\hline
\end{tabular}

the multiphase flow. As in the case of the results for the previous reservoir model without skin, among the most acceptable analytical methods regarding real absolute permeability determination is Kamal and Pan's, as well. Good results are also obtained by Raghavan's method for the permeability that is higher than in the model and for the skin that is 10.6. This is near to the original value from the simulation of 9.44 , mostly because of the advantage of the pseudo pressure function usage. Perrine's method in this model gives a very good result of skin (9.10), while Al-Khalifah's method is not acceptable in both simulations.

In the case of the Saphir program, standard and nonlinear models give acceptable results. The nonlinear model (see Figure 10) is better as absolute permeability is a little bit lower than $15 \mathrm{mD}$ and skin, which is matched also a bit smaller than the original of 9.44.

\section{Conclusions}

Determination of absolute permeability is conditio sine qua non in the petroleum production and reservoir engineering, as it strongly affects reservoir performance predictions and production rate forecasts, made by numerical simulation models. Pressure build-up test analy- sis is the most frequently used technique to calculate permeability and skin as well as other reservoir parameters. In reservoir systems with the multiphase fluid flow, more complex analysis should be conducted than in the case of a single phase flow, as was confirmed by all presented methods. In both homogenic, simulated reservoirs, with and without skin, the best results were obtained by the nonlinear model in the Saphir program. If the relative permeability curves of fluids in the reservoir are not available, the standard model can also be used with a high level of matching accuracy of the tested and modelled data. Other analytical methods for the multiphase fluid flow, based on the pressure build-up test data, can be applied to achieve approximate values of permeability.

When there is an abundance of data collected by well testing, the suggested approach of reservoir simulation usage to conduct pressure build-up tests, can be of significant importance in the determination of permeability. Although in both simulations, with and without skin, there are certain deviations between the calculated and assumed value of permeability $(15 \mathrm{mD})$, the main contribution of these results is in the possibility of their application in real multiphase reservoir systems, where it can be expected that the most reliable determination of permeability will be obtained by a nonlinear model.

\section{Nomenclature}

B - volume factor $\left(\mathrm{m}^{3} / \mathrm{m}^{3}\right)$

C - compressibility $\left(\mathrm{Pa}^{-1}\right)$

$\mathrm{c}_{\mathrm{t}} \quad$ - total compressibility $\left(\mathrm{Pa}^{-1}\right)$

$\mathrm{h} \quad-$ reservoir net thickness $(\mathrm{m})$

$\mathrm{k}$ - rock permeability $\left(\mathrm{m}^{2}\right)$

$\mathrm{k}_{\mathrm{g}} \quad$ - effective permeability of gas $\left(\mathrm{m}^{2}\right)$

$\mathrm{k}_{\mathrm{o}} \quad$ - effective permeability of oil $\left(\mathrm{m}^{2}\right)$

$\mathrm{k}_{\mathrm{rg}} \quad$ - relative permeability of gas (ratio)

$\mathrm{k}_{\mathrm{ro}} \quad$ - relative permeability of oil (ratio)

$\mathrm{k}_{\mathrm{s}} \quad$ - permeability of the damaged near wellbore region $\left(\mathrm{m}^{2}\right)$

$\mathrm{m} \quad$ - value of slope $(\mathrm{Pa}),(\mathrm{Pa} / \mathrm{s})$

$\mathrm{m}(\mathrm{p})$ - pseudo pressure (bar), $(\mathrm{Pa})$

$\mathrm{m}_{\mathrm{D}}$ - dimensionless pseudo pressure

$\mathrm{p} \quad$ - pressure (bar), $(\mathrm{Pa})$

$\mathrm{p}_{\mathrm{b}} \quad$ - bubble point pressure (bar), $(\mathrm{Pa})$

$\mathrm{p}_{\mathrm{D}}$ - dimensionless pressure

$\mathrm{p}_{\mathrm{e}} \quad$ - constant outer reservoir pressure (bar), (Pa)

$\mathrm{p}_{\mathrm{i}} \quad$ - initial reservoir pressure (bar), $(\mathrm{Pa})$

$\mathrm{p}_{\mathrm{s}} \quad-$ pressure at the outer bound of the damaged region (bar), (Pa)

$\mathrm{p}_{\mathrm{wf}} \quad$ - bottom-hole flowing well pressure (bar), (Pa)

q - flow rate $\left(\mathrm{m}^{3} / \mathrm{s}\right)$

$\mathrm{r}-\operatorname{radius}(\mathrm{m})$

$r_{e} \quad-$ reservoir radial extent $(\mathrm{m})$ 
$\mathrm{r}_{\mathrm{s}} \quad$ - radius of the damaged near wellbore region $(\mathrm{m})$

$\mathrm{r}_{\mathrm{w}} \quad-$ well radius $(\mathrm{m})$

$\mathrm{R}$ - production gas/oil ratio $\left(\mathrm{m}^{3} / \mathrm{m}^{3}\right)$

$\mathrm{R}_{\mathrm{s}} \quad$ - solution gas/oil ratio $\left(\mathrm{m}^{3} / \mathrm{m}^{3}\right)$

$\mathrm{S} \quad$ - saturation (-)

$\mathrm{t} \quad-$ time $(\mathrm{s})$

f $\quad-$ porosity (-)

$1-$ mobility $\left(\mathrm{m}^{2} / \mathrm{Pa} \mathrm{s}\right)$

$1_{\mathrm{t}} \quad-$ total mobility $\left(\mathrm{m}^{2} / \mathrm{Pa} \mathrm{s}\right)$

$\mathrm{m}-$ viscosity (Pa s)

\section{Acknowledgment}

The authors would like to thank Kappa Engineering for the usage of the Saphir program (Educational License \#9643) in this research.

\section{References}

Ahmed, T. (2010): Reservoir Engineering Handbook. 4th ed., Gulf Professional Publishing/Elsevier, Burlington, 1472 p.

Al-Khalifah, A-J.A., Aziz K. and Horne, R.N. (1987): A New Approach to Multiphase Well Test Analysis. Proceedings of the SPE Annual Technical Conference and Exhibition, Dallas, 27-30 September, Society of Petroleum Engineers, SPE 16743, https://doi.org/10.2118/16743-MS

Bourdarot, G. (1998): Well testing: Interpretation methods. Institut Francais Du Petrole Publications, Pariz, 350 p.

Gringarten, A.C. (2008): From Straight Lines to Deconvolution - The Evolution of the State of the Art in Well Test Analysis. SPEREE, 11, 1, 41-62.

Houze O.P. (2002): Why we should stop using pseudo pressures and other good old well test interpretation tools after so many years of good service. Proceedings of the SPE Annual Technical Conference an Exhibition, San Antonio, 29 September - 2 October, Society of Petroleum Engineers, SPE 77619, https://doi.org/10.2118/77619-ms

Kamal, M. M. and Pan Y. (2011): Pressure transient testing under multiphase conditions. Proceedings of the SPE Mid- dle East Oil and Gas Show and Conference, Bahrain, 2528 September, Society of Petroleum Engineers, SPE 141752, https://doi.org/10.2118/141572-ms

Karasalihović-Sedlar, D., Barbir, G. and Brkić, V. (2017): Types of fi scal regime in hydrocarbon exploration and production. The Mining-Geology-Petroleum Engineering Bulletin, 32, 1, 45-54.

Koščak Kolin, S., Čikeš, M. and Babić, V. (2013): Analiza testa porasta tlaka horizontalne bušotine. The Mining-Geology-Petroleum Engineering Bulletin, 26, 1, 1-27.

Lee, J. (1982): Well Testing. Society of Petroleum Engineers. New York, 159 p., ISBN 978-089520-317-5.

Lee J., Rollins J.B. and Spivey J.P. (2003): Pressure Transient Testing. Society of Petroleum Engineers, Austin, Texas, $376 \mathrm{p}$.

Matthews C.S. and Russell D.G. (1967): Pressure Build-up and Flow Tests in Wells. Society of Petroleum Engineers. Dallas, 163 p.

Perrine R.L. (1956): Analysis of Pressure Build-up Curves. API Drilling and Production Practice, 482-509.

Raghavan R. (1976): Well Test Analysis: Wells Producing by Solution Gas Drive. SPE Journal, 16, 4, 196-208. https:// doi.org/10.2118/5588-PA

Stewart, G. (2011): Well Test Design and Analysis. PennWell Corporation, Tulsa, $1544 \mathrm{p}$.

Strpić, K., Miličević, M. and Kurevija, T. (2017): Development of Tight Oil Resources in the USA: Exploitation Costs and Effect of Macroeconomic Indicators in a Volatile Oil Price Environment. The Mining-Geology-Petroleum Engineering Bulletin, 32, 3, 23-33.

Internet sources:

PVT Calculator (2017): Akadem Petroleum Technology Inc. Available online: https://www.pengtools.com/frontend/web/ pvtCalculator. (accessed on 28. 3. 2017).

Eclipse 100 User Course. (2017): Available online: http:// www.fanarco.net/books/Eclipse100.pdf. (accessed on 25. 4. 2017)

Saphir tutorial. (2017): Available online: https://download. kappaeng.com/download/free/tutorials/saphir/512/B01\% 20-\%20PTAEX01.pdf. (accessed on 7. 7. 2017). 


\section{SAŽETAK}

\section{Analiza testa porasta tlaka u ležištu s višefaznim protokom fluida}

Okosnica je rada određivanje apsolutne propusnosti stijene u ležištu gdje je tlak pao ispod tlaka zasićenja. U tu svrhu izrađena je simulacija sustava ležišta i bušotine s dvofaznim protokom nafte i plina primjenom softvera Eclipseıo. Osnovni su cilj simulacije izlazni podatci testova porasta tlaka jer je za dobivanje stvarnih podataka potrebno zatvoriti bušotinu na određeno vrijeme, što povisuje troškove cjelokupnoga proizvodnog procesa bušotine. U prvoj simulaciji pretpostavlja se da pribušotinska zona nije oštećena te da skin faktor iznosi nula, a u drugome je slučaju za isti sustav bušotine i ležišta uzet u obzir skin faktor od 9,44. Glavna je svrha rada temeljem analiziranih podataka testova porasta tlaka usporediti rezultate dobivene primjenom različitih metoda za određivanje propusnosti stijene u slučaju višefaznoga protoka, i to za svaki od dvaju ležišnih sustava. Odabrane metode najprije su ukratko teoretski opisane, a zatim su rezultati tih metoda uspoređeni s određivanjem propusnosti uporabom softvera Saphir za oba slučaja. Razlike u dobivenim rezultatima iznesene su u diskusiji, a zaključci rada mogu se primijeniti u stvarnim ležišnim sustavima s višefaznim protokom fluida.

Ključne riječi:

višefazni protok fluida, analiza neustaljenoga protjecanja, propusnost ležišne stijene, test porasta tlaka

\section{Authors' contribution}

Sonja Koščak Kolin (Assistant, MSc) led the research, performed the calculations, described the methods, conducted the results from Saphir.program and wrote the paper. Tomislav Kurevija (Assistant Professor, PhD) initialized the idea of the research and contributed in all obtained results from the Eclipse 100 and Saphir.programs. Dominik Grebenar (Mag. Ing., former student) made simulations in the Eclipseıoo program, prepared the figures based on the data transferred from the Eclipse and Saphir software to Excel.program. 